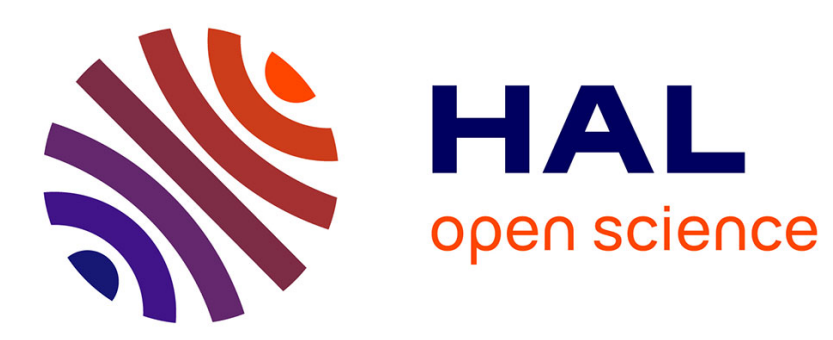

\title{
Holocene history of fire, vegetation and land use from the central Pyrenees (France)
}

Damien Rius, Boris Vannière, Didier Galop

\section{To cite this version:}

Damien Rius, Boris Vannière, Didier Galop. Holocene history of fire, vegetation and land use from the central Pyrenees (France). Quaternary Research, 2012, 77, pp.54-64. 10.1016/j.yqres.2011.09.009 . halshs-00966755

\section{HAL Id: halshs-00966755 https://shs.hal.science/halshs-00966755}

Submitted on 27 Mar 2014

HAL is a multi-disciplinary open access archive for the deposit and dissemination of scientific research documents, whether they are published or not. The documents may come from teaching and research institutions in France or abroad, or from public or private research centers.
L'archive ouverte pluridisciplinaire HAL, est destinée au dépôt et à la diffusion de documents scientifiques de niveau recherche, publiés ou non, émanant des établissements d'enseignement et de recherche français ou étrangers, des laboratoires publics ou privés. 


\title{
Holocene history of fire, vegetation and land use from the central Pyrenees (France)
}

\author{
Damien Rius ${ }^{\mathrm{a}, \mathrm{b}, *}$, Boris Vannière ${ }^{\mathrm{a}}$, Didier Galop ${ }^{\mathrm{b}}$ \\ a Laboratoire Chrono-Environnement, UMR 6249 CNRS, Université de Franche-Comté, UFR ST, 16 route de Gray, 25030 Besançon, France \\ b Laboratoire GEODE, UMR 5602 CNRS, Université Toulouse II-le Mirail, 5 allées Antonio Machado, 31058 Toulouse, France
}

\section{A R T I C L E I N F O}

\section{Article history}

Received 2 October 2010

Available online 26 October 2011

\section{Keywords}

Macroscopic charcoal

Fire regime

Human impact

Climate

Pyrenees

\begin{abstract}
A B S T R A C T
Located on a mountain pass in the west-central Pyrenees, the Col d'Ech peat bog provides a Holocene fire and vegetation record based upon nine ${ }^{14} \mathrm{C}$ (AMS) dates. We aim to compare climate-driven versus human-driven fire regimes in terms of frequency, fire episodes distribution, and impact on vegetation. Our results show the mid-Holocene (8500-5500 cal yr BP) to be characterized by high fire frequency linked with drier and warmer conditions. However, fire occurrences appear to have been rather stochastic as underlined by a scattered chronological distribution. Wetter and colder conditions at the mid-to-late Holocene transition (4000-3000 cal yr BP) led to a decrease in fire frequency, probably driven by both climate and a subsequent reduction in human land use. On the contrary, from 3000 cal yr BP, fire frequency seems to be driven by agro-pastoral activities with a very regular distribution of events. During this period fire was used as a prominent agent of landscape management.
\end{abstract}

(c) 2011 University of Washington. Published by Elsevier Inc. All rights reserved.

\section{Introduction}

Fire is a key agent of disturbance in a wide range of ecosystems from boreal biomes (Pitkanen, 2000; Tinner et al., 2006) to temperate European mountain zones (Carcaillet, 1998; Tinner et al., 1999, 2000), as well as in the Mediterranean area (Carrión et al., 2003; Noti et al., 2009; Gil-Romera et al., 2010; Vannière et al., 2011). On the millennial scale of the Holocene, controlling factors of fire regimes mostly depend on the bioclimatic characteristics (Marlon et al., 2006) and/or on the onset of human impact in these ecosystems (Abrams and Nowacki, 2008; Tinner et al., 2009). Climate controls fire regime by both ignition and fire spread-favouring conditions (composition, structure and moisture of biomass, e.g. Pausas, 2004) whereas humans change charcoal accumulation patterns through agro-pastoral activities type and intensity (Rius et al., 2009). At the global scale, fire regimes have been affected by humans for the last $250 \mathrm{yr}$ : biomass burning sharply increased at $1750 \mathrm{AD}$ before decreasing at $1870 \mathrm{AD}$ due to land-use changes and fire management (Marlon et al., 2008). However, in Europe, charcoal analyses from single sites have recorded anthropogenic forcing of fire regimes at earlier dates. For example, Turner et al. (2008) showed that climate and fire had been disconnected since $1700 \mathrm{cal}$ yr BP in Turkey. In central Switzerland, Mean Fire Interval (MFI) decreased by half $2000 \mathrm{yr}$ ago due to increasing human impact (Stähli et al., 2006). In the Mediterranean basin, the regional-scale switch from a climateregulated to a human-dominated biomass burning regime occurred between 4000 and 2000 yr ago (Vannière et al., 2010). In the Pyrenees,

\footnotetext{
* Corresponding author at: Laboratoire Chrono-Environnement, UMR 6249 CNRS, Université de Franche-Comté, UFR ST, 16 route de Gray, 25030 Besançon, France. E-mail address: damien.rius@univ-tlse2.fr (D. Rius).
}

evidence exists for linking fire and human impact from the Middle Neolithic period (Vanniere et al., 2001; Galop et al., 2002; Miras et al., 2007). Human use of fire during this period remains sporadic with a limited impact on vegetation. The threshold from which humans became the main controlling agent of fire occurrence seems to be the mid to late Holocene (i.e. the Bronze Age to Iron Age) with a clear succession of a sporadic use of fire during the Neolithic to systematic fire use from 4000 to 3000 cal yr BP (Rius et al., 2009). This shift from sporadic fire use to a predominantly anthropogenic driven fire regime was also observed in the Alps (Tinner et al., 2005). However, in the north-western central Pyrenees the natural occurrence of fire in ecosystems prior to the onset of agriculture at 7600 cal BP (Zapata et al., 2004; Galop, 2006), remains poorly known due to the lack of high-resolution fire studies. As a consequence, it is difficult to characterize natural versus anthropogenic fire regimes in terms of frequency, distribution of fire episodes, and environmental impact as it has recently been done in northern Italy (Kaltenrieder et al., 2010) or in southern Sweden (Olsson et al., 2010).

Here, we present a 10,500-yr-long charcoal and pollen record from the "Col d'Ech" peat bog (Lourdes basin, central Pyrenees, France) with the aim of 1 ) disentangling the different forcing factors controlling the fire regime, i.e. climate and human impact and 2) examining fire frequency and distribution during both non-anthropogenic and anthropogenic parts of the record.

\section{Materials and methods}

\section{Environmental settings}

The study site $\left(43^{\circ} 4^{\prime} 58.74 \mathrm{~N} ; 0^{\circ} 5^{\prime} 38.53 \mathrm{~W}, 710 \mathrm{~m}\right.$ asl $)$ is located in the west-central Pyrenees, southwest above Lourdes city (Fig. 1). This 


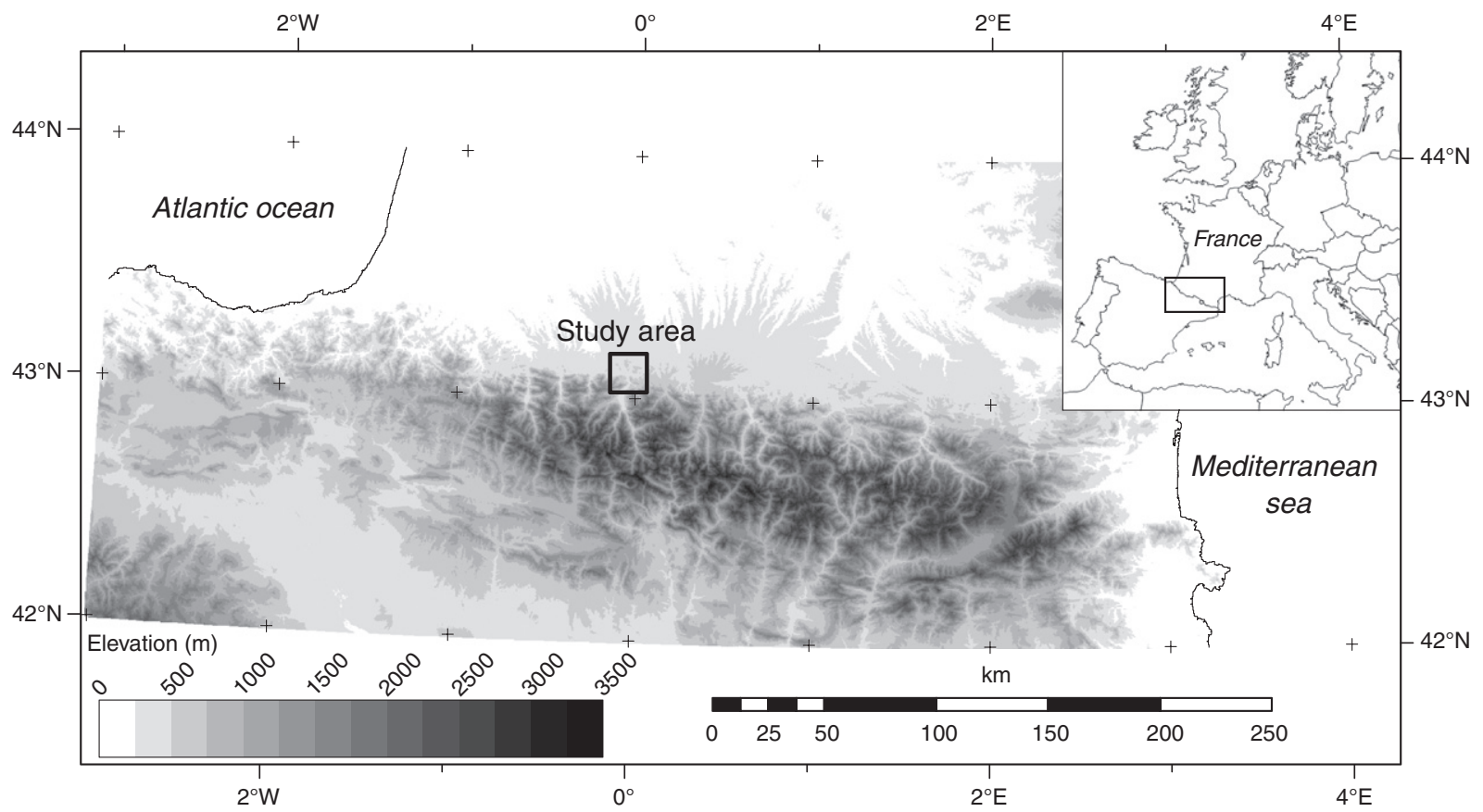

Figure 1. Elevation map of the Pyrenees mountain range with the location of the study area.

zone is characterized by a mountainous oceanic climate with mean annual precipitation of $1200 \mathrm{~mm}$. Mean annual temperature $\mathrm{T}$ is $12.5^{\circ} \mathrm{C}$ (mean summer $\mathrm{T}=18.5^{\circ} \mathrm{C}$ and mean winter $\mathrm{T}=6^{\circ} \mathrm{C}$, MeteoFrance Data, 1931-2006). Regional vegetation consists of Atlantic-type oak forest mainly dominated by Quercus robur with Corylus and Betula. Locally, the north-facing slopes (up to $900 \mathrm{~m}$ ) are covered by a mixed beech-oak forest, which is the dominant vegetation of the bioclimatic stage in the area. The ombrotrophic Col d'Ech bog is 5.3 ha in size. It is a former glacial lake which is located on a small plateau dammed by a recessional moraine at the south and by a 200-m-high-south-facing calcareous slope at the north. The peat bog has been drained and is drying out today. It is surrounded by seven farms, most of them now abandoned, and by pasture areas. The strong shelter effect from this slope combined with dry calcareous soils results in the presence of $Q$. pubescens and some Buxus sempervirens stands (Dupias, 1985).

In the central Pyrenees, there are currently two fire seasons. The main one, in extent and number of occurrence, is winter (January, February, and March), during which fires are linked to pasture management (Métailié, 1981; Ribet, 2009). The second one occurs during summer (July, August) and is linked to both accidental and natural (lightning) fires (Préfecture des Hautes-Pyrénées, 2007).

\section{Holocene human impact in the northern Pyrenees}

Archaeological data shows occupation of the Pyrenees since the Palaeolithic period by hunter-gatherer population (Bahn, 1984; Valdeyron, 2008), but the introduction of agriculture and husbandry started around $7600 \mathrm{cal}$ yr BP (Guilaine, 1994) from the Mediterranean basin at the east and from the south via the Ebro valley in Spain (PeñaChocarro et al., 2005). The first pollen evidence of agro-pastoral activities are recorded during the Early Neolithic at. 7500-7200 cal yr BP in the Basque country (Galop, 2006) and at 6800-6500 cal yr BP in the Lourdes basin (Reille and Andrieu, 1995). During the middle-to-late Neolithic (6500-4300 cal yr BP) grazing activities extended towards high mountains zones (Galop, 2006), while signs of agriculture and human occupation are increasingly recorded on the piedmont (Rius et al., 2009).
During the Bronze Age (4300-2700 cal yr BP), there were two main phases of agro-pastoral expansion, at 4100 and 3300 cal yr BP (Carozza and Galop, 2008). The first phase was characterized by an increase of both signs of agriculture and grazing activities but clearances seems to remain small. On the contrary, the second phase of agro-pastoral expansion resulted in marked deforestation. Thus, these two phases may highlight the transition from an agro-sylvo-pastoral system («slash and burn» with forested fallows) to an agro-pastoral system (Galop et al., 2002).

The Iron Age (2700-2000 cal yr BP) and the Antiquity (2000$1500 \mathrm{cal}$ yr BP) emphasize a progressive increase of the grazing pressure (Galop, 2005). The rapid development of mining activities (Monna et al., 2004) appears as a major driver of deforestation at these times.

The beginning of the Middle Ages (1500-500 cal yr BP) shows no increase in the agro-pastoral pressure but some diversification in cultivated crops (Secale cultivation) at 1500-1300 cal yr BP (Galop, 2000). Then, there are clear signs of agro-pastoral expansion from 1300$1100 \mathrm{cal} \mathrm{yr}$ BP corresponding to the Medieval growth (Bonnassie, 1989). Finally, from 1000 to $800 \mathrm{cal}$ yr BP onwards the intensification of both agro-pastoral and mining activities leads to generalized deforestation at the Pyrenean range scale (Vanniere et al., 2001).

This intensification of the agro-pastoral pressure was slowed by the medieval crisis (700-600 cal yr BP) characterized by demographic collapse (Berthe, 1984). Following this period, the effect of economic and demographic recovery on land use is clearly detectable in the paleoecological records (Galop, 2001) and is characterized by marked deforestation. Human pressure progressively peaked during this expansion phase, from 500 to 100 cal yr BP. Finally, massive rural depopulation began during the first half of the last century and promoted land-use changes at unprecedented rates, in reforestation in particular (Galop et al., 2011).

\section{Coring, lithology and chronology}

The core was taken (APAGEO device) with a Russian peat sampler (GIK type, $100 \mathrm{~cm}$ length, $10 \mathrm{~cm}$ in diameter), which avoided sediment compaction. The bore holes were located at the centre of the peat bog. Two overlapping cores of $500 \mathrm{~cm}(0-500$ and $50-550 \mathrm{~cm})$ were 
obtained. Gamma density (GD) measurements were made each $1 \mathrm{~cm}$ on the first $300 \mathrm{~cm}$, and each $5 \mathrm{~mm}$ on the remaining $200 \mathrm{~cm}$ with a Geotek MSCL (Multi Sensor Core Logger) device. This parameter was used along with sedimentary units to construct a composite sequence $(550 \mathrm{~cm})$ from the twin cores. The chronology was based on nine Accelerator Mass Spectometry (AMS, Table 1) radiocarbon dates on bulk sediments from samples picked between 20.5 and $380.5 \mathrm{~cm}$ depth. Dating was performed on bulk sediments after removing rootlets, because the high organic content enabled us to do so, without reservoir effect (Blaauw et al., 2004). Calibration to cal yr BP was made using CALIB software (Stuiver and Reimer, 1993) version 6.0.1., based on the dataset IntCal09 (Reimer et al., 2009). To predict ages along the entire profile, we used a mixed-effect regression model (Heegaard et al., 2005). The section analysed for charcoal $(0-370 \mathrm{~cm})$ covers the last $10,500 \mathrm{yr}$ (Fig. 2), i.e. almost the entire Holocene.

The sedimentary record (Fig. 2) consists of lacustrine silty clay (400$387 \mathrm{~cm})$, a 2-cm-thick light grey clay layer (387-385 cm), dark brown organic silts (385-330 cm), brown fibrous peat $(330-10 \mathrm{~cm})$ and a terrigenous unit $(10-0 \mathrm{~cm})$.

\section{Macroscopic charcoal analysis}

Contiguous samples of $2.6 \mathrm{~cm}^{3}$ were retrieved with a needleless syringe at $1 \mathrm{~cm}$ intervals, soaked in a $10 \% \mathrm{NaOH}$ solution during $24 \mathrm{~h}$, then in a $6 \% \mathrm{H}_{2} \mathrm{O}_{2}$ solution during the same time in order to bleach non-charcoal organic material and thus make identification easier (Rhodes, 1998). Because we aim to reconstruct local fire history, charred particle quantification was made by sieving with a $150 \mu \mathrm{m}$ mesh size. Both charcoal particle number and area concentrations were estimated under a binocular microscope at a $50 \times$ magnification with a reticule grid of $10 \times 10$ squares of $62.5 \cdot 10^{-3} \mathrm{~mm}^{2}$ each. Ten increasing size classes were defined $(31.25-62.5,62.5-125, \ldots, 187.5-$ $25010^{-3} \mathrm{~mm}^{2}, \ldots$.. . Charcoal identification was restricted to the criteria usually defined in literature (Umbanhowar and McGrath, 1998; Enache and Cumming, 2006, 2007).

CHArcoal Concentration ( CHAC; $\mathrm{mm}^{2} \cdot \mathrm{cm}^{-3}$ ) was expressed as CHarcoal Accumulation Rate (CHAR; $\mathrm{mm}^{2} \cdot \mathrm{cm}^{-2} \cdot \mathrm{yr}^{-1}$ ) based on sedimentation rate estimated by the depth-age model. The CHAR of particles $>562.5 \cdot 10^{-3} \mathrm{~mm}^{2}$ (hereafter referred to as 'large charcoal fragments'), which can be regarded as a good indicator of local fires and could be compared with fire episodes detected and reconstructed fire frequency, is plotted on Figure 3.

Table 1

AMS radiocarbon dates from the "Col d'Ech" peatbog measured by the Poznan Radiocarbon Lab., Poland.

\begin{tabular}{llllll}
\hline $\begin{array}{l}\text { Sample } \\
\text { depth }(\mathrm{cm})\end{array}$ & Lab. code & Type & $\begin{array}{l}\text { AMS radiocarbon } \\
\text { date, }{ }^{14} \mathrm{C} \text { yr BP }\end{array}$ & $\begin{array}{l}\text { Cal yr BP } \\
{[2 \sigma \text { range }]} \\
\text { probability area }\end{array}$ & $\begin{array}{l}\Delta{ }^{13} \mathrm{C} \text { values } \\
(\%)\end{array}$ \\
\hline Ech06 20.5 & $\begin{array}{l}\text { Poz- } \\
23135\end{array}$ & Peat & $645 \pm 30$ & $555-668$ & -33.1 \\
Ech06 46.5 & $\begin{array}{l}\text { Poz- } \\
\text { 23136 }\end{array}$ & Peat & $1210 \pm 30$ & $1059-1256$ & -27.5 \\
Ech06 105.5 & $\begin{array}{l}\text { Poz- } \\
\text { Poz }\end{array}$ & Peat & $2770 \pm 30$ & $2788-2946$ & -27.9 \\
Ech06 145.5 & $\begin{array}{l}\text { Poz- } \\
\text { Poz }\end{array}$ & Peat & $3615 \pm 35$ & $3836-4071$ & -32.6 \\
Ech06 190.5 & $\begin{array}{l}\text { Poz- } \\
\text { Poz }\end{array}$ & Peat & $4550 \pm 40$ & $5049-5434$ & -27.4 \\
Ech06 228.5 & $\begin{array}{l}\text { Poz- } \\
23139\end{array}$ & Peat & $5090 \pm 40$ & $5743-5917$ & -31 \\
Ech06 287.5 & $\begin{array}{l}\text { Poz- } \\
23140\end{array}$ & Peat & $6420 \pm 40$ & $7274-7422$ & -28.1 \\
Ech06 329.5 & $\begin{array}{l}\text { Poz- } \\
23141\end{array}$ & Peat & $7430 \pm 50$ & $8019-8308$ & -31 \\
Ech06 380.5 & $\begin{array}{l}\text { Poz- } \\
27285\end{array}$ & Bulk & $9890 \pm 50$ & $11,202-11,597$ & -23.4 \\
\hline
\end{tabular}

Inferred fire frequency (IFF)

The calculation of Inferred Fire Frequency (IFF, Clark, 1995; Long et al., 1998; Gavin et al., 2003; Lynch et al., 2004) is based on the decomposition approach (Higuera et al., 2010) whose goal is to delineate the two source components in the charcoal signal (Clark and Patterson, 1997): background charcoal (BCHAR) and peak component.

The whole procedure was performed under the $\mathrm{R}$ open-source statistical environment (R Development Core team, 2009) and consisted of the following steps: 1) The CHAR record was resampled to equaltime intervals (as in Long et al., 1998) using a window corresponding to the mean sedimentation rate of the record $\left(25 \mathrm{yr} \mathrm{cm}^{-1}\right)$, 2) The data were log-transformed (LogChar) to homogenize variance, 3) Background CHARcoal (BCHAR) was estimated with a Loess filter (250 yr moving window), allowing calculation of the Peak Component ( $\mathrm{PC}=$ ( $\log )$ CHAR - ( $\log )$ BCHAR) as a residual, 4) A threshold value (Tv) within the range of values with the lowest sensitivity to the number of peaks detected was derived by plotting a frequency distribution histogram of peak component against a cumulative curve of peak number (Empirical Cumulative Distribution Function; ECDF). This is an essential step to separate noise-related variation from local fire episodes. All peaks above this Tv were considered as single fire episodes and, 5) Fire episodes frequencies were smoothed using a 500-yr moving window (K1D software, Gavin et al., 2006). The decomposition of the charcoal record is plotted on Figures 3 and 4. Finally (6), Mean Fire Interval (MFI) was calculated by dividing the difference in age between the first and the last fire episode by the number of fire intervals $(n-1$, where $n$ is the number of fire episodes) of a given period, while Fire Return Interval (FRI) is the difference in age between two fire episodes.

\section{Pollen analysis}

Subsamples for pollen analysis consisted of $1 \mathrm{~cm}^{3}$ cubes taken at $5 \mathrm{~cm}$ intervals. Pollen preparation followed standard methods using treatment with $10 \% \mathrm{KOH}$ ( $35 \mathrm{mn}$ ), $\mathrm{HF}(24 \mathrm{~h}$ ), sieving at $150 \mu \mathrm{m}$, acetolysis ( $7 \mathrm{mn}$ ) and final mounting in glycerine (Faegri and Iversen, 1989). A minimum of 450 terrestrial pollen grains were counted in each sample. Alnus, Cyperaceae, aquatic taxa and fern spores were excluded from the pollen sum to avoid over-representation by aquatic and local taxa. All pollen types are defined according to Faegri and Iversen (1989) and Beug (2004), although some identification required the use of pollen atlases (Reille, 1992-98) or pollen collections from the laboratory GEODE (University of Toulouse II-Le Mirail). Figure 5 presents a percentage pollen diagram with major arboreal taxa, anthropogenic indicators and synthetic curves of cultivated crops and Anthropogenic Pollen Indicators (API).

\section{Results}

Lithology and chronology

Lithology and radiocarbon dates show a single major shift in sedimentation during the Holocene. The shift is characterized by accumulation of silts that become more and more organic as the basin progressively filled up. This sedimentation change is only visible in the lithological log and is not reflected in gamma density measurements (Fig. 2).

This transition from silt to peat at $330 \mathrm{~cm}(\sim 8200 \mathrm{cal} \mathrm{yr} B P$, Table 1), which marks the final step of infilling of the lake basin, is characterized by an increase in sedimentation rate (between 370 and $300 \mathrm{~cm}$ mean sedimentation rate $=0.17 \mathrm{~mm}^{2} \cdot \mathrm{yr}^{-1}$, from 330 to $290 \mathrm{~cm}=0.47 \mathrm{~mm}^{2} \mathrm{yr}^{-1}$ ).

\section{Macroscopic charcoal record and fire frequency}

Charcoal counts ranged from 0 to 3811 with a mean of 191 and a median of 92. The charcoal record emphasizes four main patterns (Fig. 3a). 


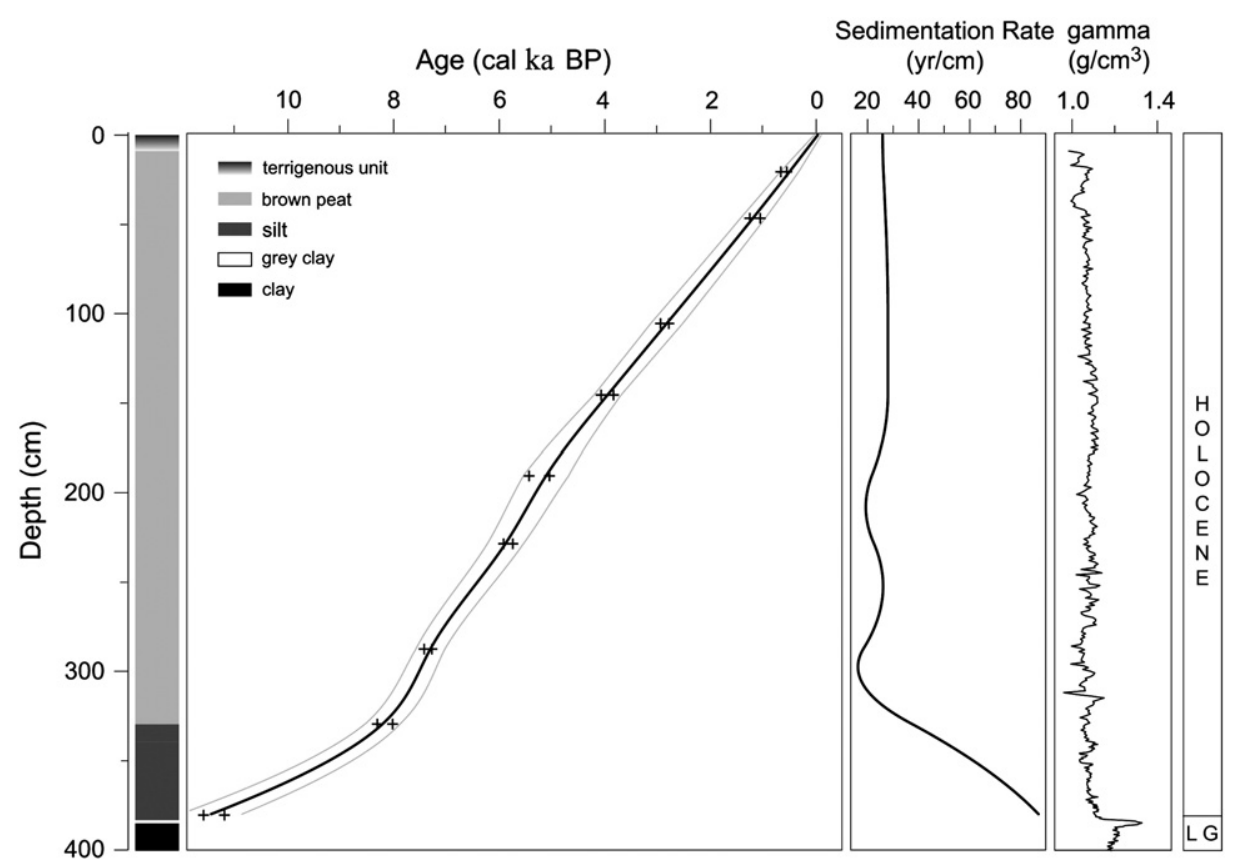

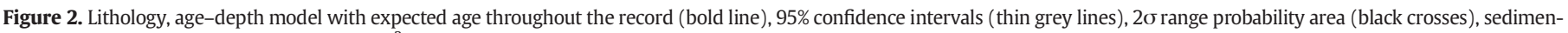
tation rate $(\mathrm{yr} / \mathrm{cm})$ and Gamma density $\left(\mathrm{g} / \mathrm{cm}^{3}\right)$. LG = Late Glacial.

From 10,500 to 8000 cal yr BP, there is only one distinguishable peak above a steady BCHAR with low variability (Fig. 3b). From 8000 to 3900 cal yr BP, CHAR and BCHAR show strong variability and remain high except during 7500-7000, 6500-6000 and 5000-3900 cal yr BP. It is during this mid-Holocene phase that charcoal accumulation reaches its highest values ( 4000 charcoal particles/sample, at 5500 cal yr BP).

Then, the phase between 3900 and 2900 cal yr BP is characterized by a charcoal accumulation almost equal to zero. Finally, from $2900 \mathrm{cal}$ yr BP onwards, background accumulation is rather low but with high variability, and well-defined peaks.

Patterns of large charcoal-fragment accumulation follow CHAR until 6500 cal yr BP (Fig. 3d). From this point there is a general decrease to zero (reached $3900 \mathrm{cal} \mathrm{yr} \mathrm{BP).} \mathrm{It} \mathrm{is} \mathrm{noteworthy} \mathrm{that} \mathrm{these} \mathrm{millimetre-}$ sized particles are absent during the 5600-5400 cal yr BP interval which encompasses the highest CHAR peak of the record. After $3900 \mathrm{cal}$ yr BP large charcoal fragments again regularly contribute to CHAR until 1700 cal yr BP.

Forty-four fire episodes were detected along the record from 8450 to 475 cal yr BP (Figs. 3d and 4). There are no fires detected between 10,500 and $8500 \mathrm{cal} \mathrm{yr}$ BP. Three main phases of high fire frequency are recorded: $8500-6500 \mathrm{cal}$ yr BP (up to 4.5 fires/500 yr, MFI=155 yr) with an intermediate decrease between 7500 and 7200 cal yr BP (no fire episodes); $6000-5000$ cal yr BP (up to 5 fires/500 yr, MFI $=160 \mathrm{yr}$ ) reaching the maximum of the record, and a last one $2900-400$ cal yr BP (up to $3.5 \mathrm{fires} / 500 \mathrm{yr}, \mathrm{MFI}=160 \mathrm{yr}$ ) with regular fire occurrences and a two-step increase in fire frequency at 2900 and 1700 cal yr BP. On the contrary, IFF emphasizes three main phases of low fire frequency between 6500 and 6000 cal yr BP (down to 1.3 fires/500 yr) and no fire episodes detected at all between 4900 and 4500 and between 3900 and 2900 cal yr BP.

Considering the whole record, the main high fire-frequency phases occur between 8500 and 5000 cal yr BP (i.e. the mid-Holocene) and during the last $3000 \mathrm{yr}$ (i.e. the late Holocene). However, this last period shows slightly lower frequency than before with less variability (Fig. 6).

Vegetation history

Pollen analysis describes a Holocene vegetation succession which is in accordance with the previous work of Mardones and Jalut (1983) and
Reille and Andrieu (1995) in the Lourdes basin. The Col d'Ech pollen record yields some unprecedented results concerning both the dynamics of specific taxa such as Betula as well as human impact. Six local pollen assemblages zones (LPAZ) were defined using a stratigraphically constrained cluster analysis (Fig. 5); CONISS (Grimm, 1987).

- Zone Ech 1 (12,000-10,500 cal yr BP) corresponds to the onset of the Holocene with the rapid expansion of forest stands dominated by Quercus. However, the vegetation cover remains relatively open as evidenced by the steady presence of Poaceae.

- Zone Ech 2 (10,500-7250 cal yr BP). This zone marks the transition from an oak-dominated landscape to a more closed one as it is characterized by the development of Corylus synchronous with the decrease of Poaceae. To a lesser extent, Ulmus also develops in the forest stands of the area. In the middle of this zone, an increase of Cyperaceae followed by an increase of Sphagnum marks the transition from a lacustrine to a peat system around $8200 \mathrm{cal}$ yr BP.

- Zone Ech 3 (7250-5500 cal yr BP) features abrupt changes in the local vegetation structure: a decrease of Corylus and an increase of Poaceae until 6600 cal yr BP follow the development of Betula at $6700 \mathrm{cal}$ yr BP. Then a second increase of Poaceae is recorded towards the end of the zone. The development of grassland vegetation is also underlined by the regular occurrences of Cichorioideae throughout this period. Cerealia-type pollen appears at the beginning and at the end of the zone (at 7100 and $5600 \mathrm{cal}$ yr BP respectively).

- Zone Ech 4 (5500-3600 cal yr BP) is mainly characterized by the increase of arboreal pollen percentages: Quercus, Corylus together with the local settlement of Alnus around the peat bog. This zone also emphasizes an increase in percentages of Abies, the first occurrences of Fagus, and high amplitude variations of Betula. Anthropogenic Pollen Indicators (API) slightly increase between 5000 and 4000 cal yr BP as shown by the regular occurrences of Plantago and Plantago lanceolata, Urticaceae, Rumex and Cerealia-type pollen.

- Zone Ech 5 (3600-2600 cal yr BP) starts with the main botanical event of the late Holocene which is the settlement of Fagus and the shift from a Quercus-dominated forest (with Ulmus, Tilia, Fraxinus and Corylus) to a mixed beech-oak forest, suggesting a shift to more humid conditions. The beginning and the end of this zone are characterized by high amplitude variations in percentages of Betula and to a lesser 


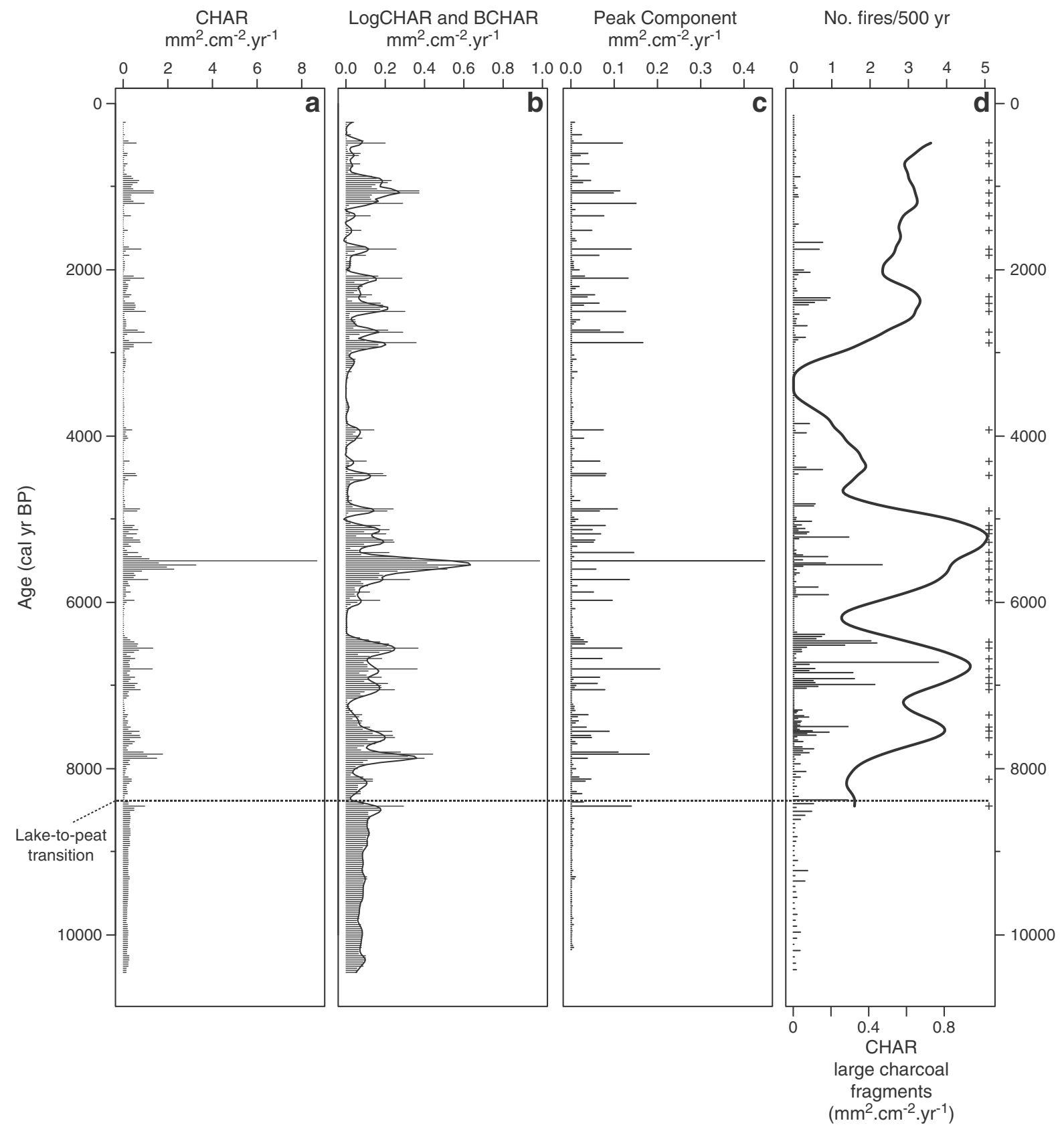

Figure 3. Inferred fire frequency (IFF) results: (a) raw CHAR, (b) LogCHAR (bars) and BCHAR (bold line), (c) Peak Component ( $\log C H A R$ - $\log (\mathrm{BCHAR})$ ), and (d) CHAR of large charcoal fragments with smoothed number of fires over a $500 \mathrm{yr}$ window and detected fire episodes (black crosses).

extent by those of Corylus. API increase at the middle of the zone (at 3300 cal yr BP) with regular occurrences of Plantago lanceolata, Urticaceae, Rumex and isolated records of Cerealia-type pollen.

- Zone Ech 6 (2600-50 cal yr BP) is mainly characterized by the abrupt increase of API and a long-lasting decrease of arboreal pollen. It can be divided into two subzones. Zone Ech 6a emphasizes the progressive degradation of the vegetation cover. All the mixed beech-oak forest taxa decrease, especially Fagus and Corylus. Zone Ech $6 \mathrm{~b}$ is the continuation of the previous one, with an even more marked decrease in percentages of arboreal pollen (Fagus in particular) and a significant increase of Poaceae percentages. Human impact became stronger as underlined by the continuous curve of cultivated crops, Plantago lanceolata, the regular occurrences of meadows taxa (Asteraceae, Cichorioideae, Brassicaceae), nitrophilous taxa (Rumex acetosa type, Urticaceae) and by the diversification of cultivated crops (regular occurrence of Secale from 800 cal yr BP).

\section{Discussion}

A complete Holocene fire record potentially encompasses the effects of climatic variations, biomass changes (type and structure), evolving sedimentary processes, and anthropogenic disturbances. All these potential forcing factors interact from local to regional scale.

\section{Holocene climate changes and fire}

Available pollen data and the first fire history studies undertaken in the northern slope of the Pyrenees (Vanniere et al., 2001; Galop et al., 2002; Miras et al., 2007) led us to assume pre-agricultural fire regime (i.e. pre-Neolithic) to be weak (Rius et al., 2009). This assumption was based on (1) the irregular and weak character of human activities before the Neolithic (7800 cal yr BP), (2) the assumed low flammability 


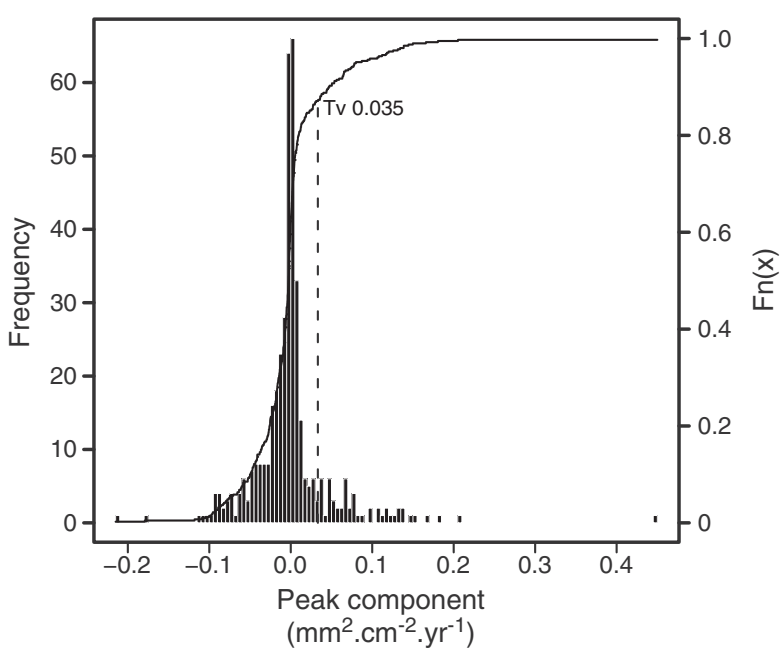

Figure 4. Histogram of sensitivity analysis for threshold-value selection. Noise-related variation and right-hand tail distribution, i.e. charcoal accumulation anomalies corresponding to local fire episodes, are separated by the threshold value (Tv, dotted line) chosen to identify local fire episodes. The separation between these two populations is where both the histogram and the cumulative curve emphasize a break and a plateau, respectively (Lynch et al., 2004).

of the forest stand types in the area (e.g. Clark et al., 1989) and (3) the scarcity of natural fire in present ecosystems.

Between 10,500 and 8500 cal yr BP, the relatively high values of CHAR with little variability which enable us to detect only one fire episode (at 8500 cal yr BP) may be explained by intra-lake processes such as charcoal particle transfer from the lake shore to the deep zone, reworking (Whitlock and Millspaugh, 1996) and a low sedimentation rate that concentrates and reduces the variability of CHAR. This may be the reason why the decomposition method is here ineffective in detecting any fires. However, the magnitude of CHAR suggest regular wildfire occurrence, probably linked with increasing biomass during the early Holocene. High fire activity during this period is recorded at the European scale (Power et al., 2008) and the occurrence of local fire is also supported by peaks in large charcoal fragments (Figs. 3 and 5).

Then, the major sedimentary change of the « $\mathrm{Col} d$ 'Ech » record between 8019 and $8308 \mathrm{cal} \mathrm{yr} \mathrm{BP} \mathrm{(Table} \mathrm{1),} \mathrm{is} \mathrm{the} \mathrm{lake} \mathrm{to} \mathrm{peat} \mathrm{transition.}$ The synchrony with the 8200 cal yr BP cold event (Alley et al., 1997) may indicate that climate forcing is responsible for that phenomenon. However, there are three other raised bogs in the immediate vicinity of the Col d'Ech: Biscaye, Le Monge and Lourdes. Those bogs are filled paleolakes where the transition from organic gyttja to peat was respectively estimated at $5950 \pm 55 \mathrm{BP}(6660-6930 \mathrm{cal} \mathrm{yr} \mathrm{BP}), 9200 \pm 60 \mathrm{BP}$ (10,240-10515 cal yr BP) and at the beginning of the Late Glacial period (according to the pollen stratigraphy, Reille and Andrieu, 1995). The heterogeneity of these dates suggests that the infilling of those paleolakes is a local phenomenon and rules out regional forcing factors such as climate. Moreover, the infilling dynamic is clearly visible in the pollen data with the successive increase of Cyperaceae and Spaghnum, the latter evidencing the beginning of peat formation (Fig. 5).

Following this phase with no fire episodes detected, the mid-Holocene exhibits increased fire frequency from 8200 to 5000 cal yr BP. These results are in accordance with the high fire activity during the same period recorded in Lake Lourdes (Rius et al., 2011) and in the north-western Mediterranean area (Vannière et al., 2011) at the same latitude. This concordance between local and regional fire history suggest the predominance of a regional climate control (Ali et al., 2009). As shown by pollen-based temperature reconstructions (Renssen et al., 2009) and glacier level studies in the Alps (Nicolussi et al., 2005, 2009; Joerin et al., 2006, 2008), the mid-Holocene was a phase of increasing summer temperature (Holocene Thermal Maximum, HTM) at the regional to continental scale (Renssen et al., 2009). The correspondence between high fire frequency and the HTM thus suggest that warmer conditions promoted increased fire frequency.

Some authors also state that increased fire frequency could be enhanced by increased moisture (Turner et al., 2008). However, this mechanism may be effective in fuel-limited environment, such as arid ecosystems, where the increase of moisture level results in increasing biomass and thus fuel build-up. This is obviously not the case in the western Pyrenees which are under oceanic influence.

From 5000 to 3000 cal yr BP onwards, the regional decrease of summer temperatures (Renssen et al., 2009) was synchronous with the establishment of Fagus sylvatica in the Pyrenean forests underlining a climate cooling (increasing precipitation and/or atmospheric humidity, Jalut et al., 1996) recorded at the western European scale (Magny et al., 2009). The absence of recorded fires during a millennium (39002900 cal yr BP, Fig. 5) suggests that increased moisture, promoting taxa such as Fagus with low specific flammability (Clark et al., 1989), could have inhibited fire occurrence. In contrast, the high level of fire frequency during the last $3000 \mathrm{yr}$ seems disconnected from this longterm cooling trend and other controls must be investigated.

\section{Land-use changes, fire regime and vegetation}

During the early Holocene, the mode of subsistence of Mesolithic (11,700-7800 cal yr BP) people was hunting-gathering in small nomadic groups (Valdeyron, 2008), which implies weak environmental imprints. Besides, there is no pollen evidence for agro-pastoral activities until $7100 \mathrm{cal}$ yr BP. We can thus reasonably assume that there was locally no fire used with agro-pastoral purposes before this date. In the same way, it seems unlikely that such a human occupation could have influenced sedimentary pattern (lake-to-peat transition) at the Col d'Ech.

Therefore, between 8200 and 6000 cal yr BP signs of human impact are scarce (no Cerealia-type pollen is found before $7100 \mathrm{cal}$ yr BP, and therer are only sparse and isolated occurrences of meadow taxa before 7250 cal yr BP), but the single and isolated occurrence of Cerealia-type pollen at 7100 cal yr BP (Early Neolithic, Fig. 5) is well correlated with AP decrease, between two fire episodes (at 7350 and 7050 cal yr BP). It may thus indicate the first local forest clearance for agriculture.

Between 6000 and $5000 \mathrm{cal} \mathrm{yr} \mathrm{BP,} \mathrm{at} \mathrm{the} \mathrm{Middle} \mathrm{to} \mathrm{Late} \mathrm{Neolithic}$ transition, fire episodes are synchronous with Cerealia-type pollen occurrences (at 5700, 5550 and 5150 cal yr BP). Cultivation seem to have a large but temporary impact on the vegetation as underlined by the successive decrease/increase of AP percentages, (Fig. 5, transition between zones Ech 3 and Ech 4). This temporary impact is likely linked with non-permanent agriculture as underlined by the centennial to multi-centennial intervals between Ceralia-pollen type occurrences. Betula seems particularly favored by these temporary clearances (Fig. 5). This agricultural phase and its impact on vegetation fits well with previous results about Neolithic fire clearances in the north-western Pyrenean piedmont (Galop, 1998; Galop et al., 2002; Rius et al., 2009). However, the duration and the high fire frequency (up to 5 fires/ $500 \mathrm{yr}$ ) compared to the sporadic occurrences of Cerealia-type pollen suggests that climate remains the major control over the fire regime, all the more so as fire frequency is synchronous from local to regional scale (as discussed above). Consequently, human influence cannot be totally ruled out, but could be considered a secondary forcing factor.

After 5000 cal yr BP our results show sporadic human impact from Late Neolithic to Early Bronze Age (Fig. 5), but both pollen and CHAR patterns show no long-lasting effects on vegetation: fire frequency and CHAR gradually decrease from 5000 to 3900 cal yr BP (4 fires episodes in a millennia), while AP percentages remain steady. High-amplitude successive increases of Betula percentages (from 10 to 40-60\%) alternate with decreases of both Quercus and Corylus which are synchronous with fire episodes. This suggests that the light-demanding Betula recolonized previously open spaces in the mixed-oak forest and was then 


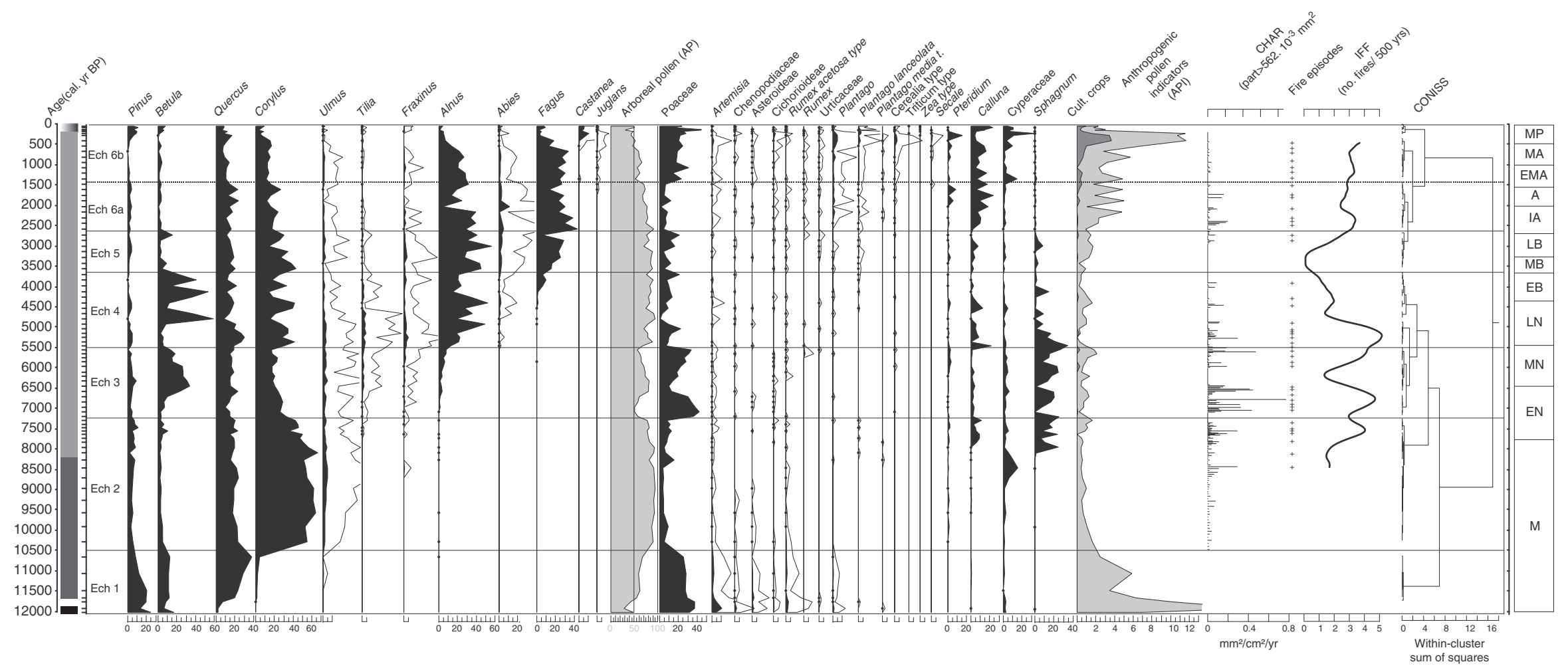

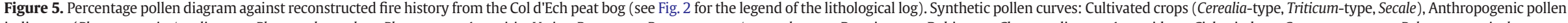

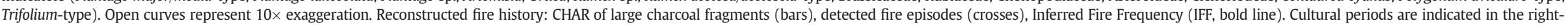

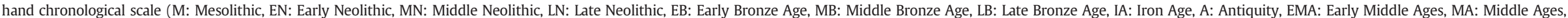
MP: Modern period). 
a

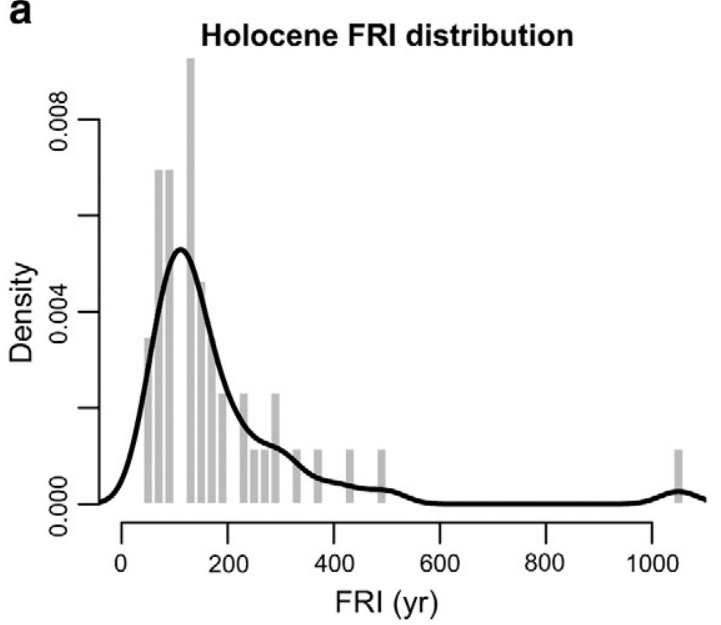

b

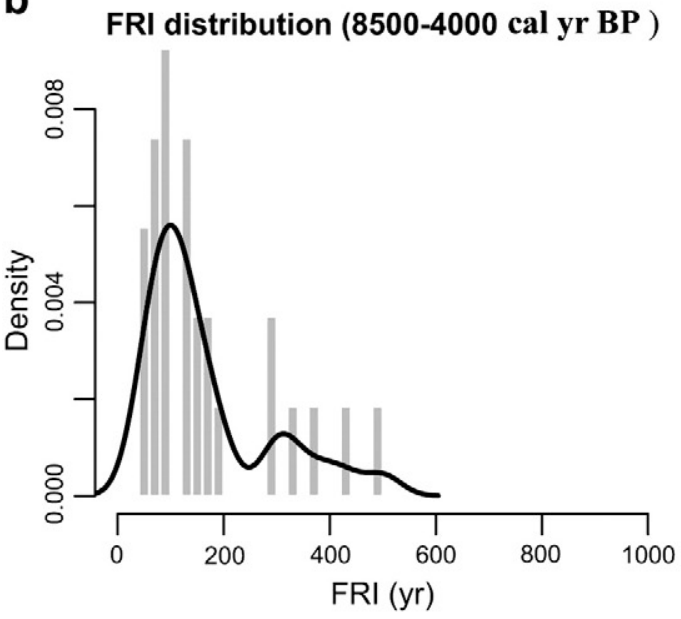

C

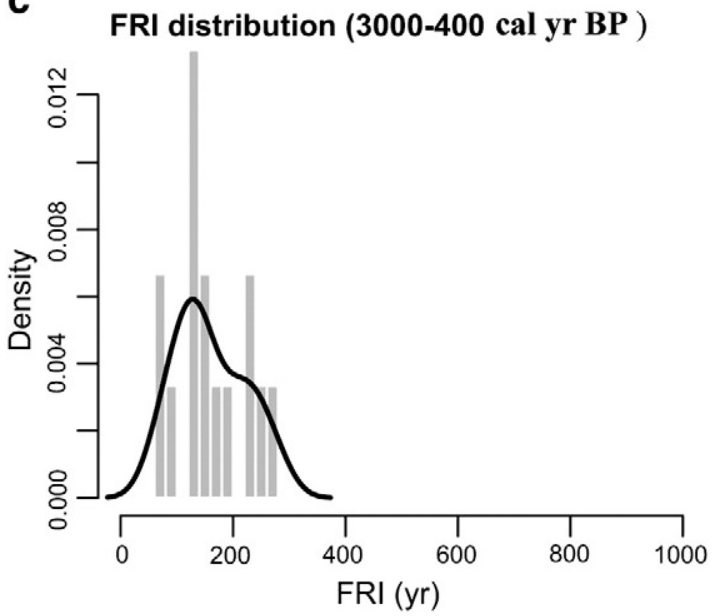

Figure 6. Density histograms of Fire Return Interval (FRI): (a) over the whole record, (b) between 8500-4000 cal yr BP and (c) between 3000-400 cal yr BP.

progressively outcompeted by other tree taxa. These clearances were probably performed for grazing activities as underlined by the slight increase of API without Ceralia-pollen type until $4250 \mathrm{cal}$ yr BP. In the northwesten Pyrenean piedmont the Neolithic-to-Bronze Age transition is usually a period of decreasing agricultural activities (Galop et al., 2007; Carozza and Galop, 2008).
The 3900-2900 cal yr BP fire-free period is concomitant with a decrease of agricultural indicators and a slightly progressive increase of API. This trend is consistent with the phenomenon of grazing overcoming agricultural activities at the regional scale for sites above 500 masl (Galop et al., 2007; Carozza and Galop, 2008). However, the absence of recorded fires for $1000 \mathrm{yr}$ together with clear signs of reforestation (AP percentage increase) underlines that grazing pressure was probably moderate. It is also probable that the climate cooling phase occurring during these period (see above) may have impacted agropastoral activities in climate change-sensitive habitats such as pile dwellings (Magny, 2004) or mountains zones (Galop et al., 2007).

Finally, the shift from a sporadic fire use to anthropogenic control over the fire regime can be assessed from $2900 \mathrm{cal}$ yr BP, at the Bronze-to-Iron Age transition, when the shift from agro-sylvo-pastoral to agro-pastoral system was achieved. The first increase of fire frequency (up to 2.5 fires/500 yr, Fig. 5) between 2900 and 1700 cal yr BP is synchronous with a sharp increase in API percentages, AP decrease and sparse occurrences of Cerealia-type pollen. This might indicate a first phase of landscape opening with the probable dominance of grazing over agricultural activities. Those fire clearances are characterized by punctual Fagus decreases and by temporary recovery of secondary taxa such as Pteridium and Corylus during fire-free intervals (2000-1750 and $1750-1500$ cal yr BP). The dynamic of the later taxa suggest moderate land use that enables temporary encroachment and also the use of fire as a "cleaning tool" (Rius et al., 2009), i.e. the use of fire to prevent colonization and maintain spaces open and available for grazing and/ or cultivation. Those anthropogenic disturbances favoring Pteridium after fires are well-known in Western Europe (Iversen, 1956; Valsecchi et al., 2010).

In a second step (1700-200 cal yr BP, Fig. 5) which begins at the transition between Antiquity and Early Middle Ages, the Cerealia-type curve becomes continuous and a general increase of API (Plantago and Plantago lanceolata in particular) is synchronous with a second increase in fire frequency (up to 3-4 fires/500 yr) and a marked decrease trend in AP percentages. These results suggest an accentuation of previously observed trends, with evidence for more permanent agriculture and diversification in cultivated crops. The increase and the regularity of fire occurences results in the suppression of temporary recovery as underlined by the flat trend of Corylus percentages and the quasidisappearance of Pteridium. The abrupt decrease of AP from $700 \mathrm{cal} \mathrm{yr}$ $\mathrm{BP}$ and in Fagus in particular indicates an intensification of land use (Galop and Jalut, 1994; Valsecchi et al., 2010) corresponding to the Medieval growth (Galop, 2000): all the watershed of the peat bog was probably cleared and used, even the north-facing slopes (where Fagus is preferentially established) which are supposed to be less favourable for agro-pastoral activities.

\section{Climatic versus anthropogenic fire frequency}

Inferred fire frequency (IFF) and mean fire interval (MFI) provides a tool to understand the role of fire within the ecosystem linked with climatic, biomass, and/or anthropogenic controls (Whitlock et al., 2010). Multiproxy comparison with pollen, archaeological data, independent climatic proxy, can help us to disentangle those forcing factors from each other.

Here the MFI is $155 \mathrm{yr}$ for the $8500-4000$ cal yr BP period, $160 \mathrm{yr}$ between 3000 and $400 \mathrm{cal} \mathrm{yr} \mathrm{BP,} \mathrm{and} 230 \mathrm{yr}$ for the entire record. There is no significant difference between those values which means that human impact probably did not enhanced fire frequency. This feature was also observed by Vannière et al. (2008) in northern Italy. The signature for anthropogenic control here lies in the temporal distribution of firereturn interval (Olsson et al., 2010).

Indeed, the distribution of Fire Return Intervals (FRI, Fig. 6) shows scattered return intervals with a highly right-skewed distribution between 8500 and 4000 cal yr BP (Fig. 6b) and a distribution centred around $200 \mathrm{yr}$ between 3000 and $400 \mathrm{cal} \mathrm{yr} \mathrm{BP} \mathrm{(Fig.} \mathrm{6c).} \mathrm{We} \mathrm{assume}$ 
the scattered distribution of FRI between 8500 and 4000 cal yr BP to be linked with 1) the combined influence of natural and anthropogenic forcing factors over fire regime especially during the last two millennia of this phase, and 2) with the instability of climate and above all with the randomness of climate control over fire regime (Olsson et al., 2010) in a not-fire-prone ecosystem all the more so as local factors (hydrography, topography, vegetation patchiness and type) modulate the fire-climate relationship (Carcaillet et al., 2001; Heyerdahl et al., 2001). Indeed, even under increased temperature and seasonal drought during the HTM, the concomitance of all favourable factors to fireignition and spread in such a bioclimatic context (i.e. seasonal drought, biomass accumulation, vegetation moisture) appears highly stochastic (Enache and Cumming, 2009).

The bell-shaped distribution of FRI from 3000 to 400 cal yr BP could be interpreted as the strong predominance of a forcing factor freed from other controls. As discussed above, this forcing factor seems to be human activities related to agriculture.

This high fire frequency with regular episodes sustained by agropastoral activities becoming progressively permanent seems to have an impact on forest cover. It has been demonstrated in the Eastern Pyrenees that repeated prescribed burning in actual conditions has an effect in reducing encroachment by shrubby vegetation comparable with those of wildfires (Montané et al., 2009). Therefore, we suggest that fire played a prominent role in landscape opening during the last $3000 \mathrm{yr}$. However, fire itself cannot be considered as the only factor of forest clearances. Indeed, it is more likely to see this long term decreasing trend in arboreal pollen percentages as the consequence of the combined effect of regular fires, permanent agro-pastoral activities and probably increasing demographic pressure. It also underlines that the Bronze-to-Iron Age transition (Carozza and Galop, 2008; Bal et al., 2010) and the Iron Age in particular were key turning points in anthropogenic fire use.

\section{Conclusions}

The "col d'Ech" fire and vegetation record emphasize climate-driven and human-driven fire frequency phases which differ in timing and pace of fire episodes and in their impact on vegetation. Comparison among quantitative reconstruction of fire frequency, vegetation and climate history is a key for understanding the complex mechanisms controlling past fire regimes. Our main results are as follows:

(1) The mid-Holocene high fire frequency (8500-5000 cal yr BP) is controlled by climate under the Holocene climatic optimum. Sporadic agricultural activities also have an impact on fire frequency especially between 6000 and 5000 cal yr BP.

(2) The mid-Holocene fire frequency, before the onset of permanent agriculture, is higher than expected in such a bioclimatic context.

(3) High fire frequency during the last $3000 \mathrm{yr}$ is mainly controlled by agro-pastoral activities.

Finally, these results also suggest that the current massive reforestation due to land abandonment, combined with the actual warming, may have an increasing impact on fire frequency.

\section{Acknowledgments}

This study was funded by the research programme "ACR Rythmes et causalités de l'anthropisation en milieu montagnard" (French Ministry of Research, French Ministry of Culture, CNRS) and by the ANPYR program (FEDER and Western Pyrenees National Park headed by D. Galop. The authors express their sincere thanks to Michael Coughlan for his help with the English language. The comments of Jean-Nicolas Haas and an anonymous reviewer greatly helped to improve the manuscript.

\section{References}

Abrams, M.D., Nowacki, G.J., 2008. Native Americans as active and passive promoters of mast and fruit trees in the eastern USA. The Holocene 18, 1123-1137.

Ali, A.A., Carcaillet, C., Bergeron, Y., 2009. Long-term fire frequency variability in the eastern Canadian boreal forest: the influences of climate vs. local factors. Global Change Biology 15, 1230-1245.

Alley, R.B., Mayewski, P.A., Sowers, T., Stuiver, M., Taylor, K.C., Clark, P.U., 1997. Holocene climatic instability: a prominent, widespread event $8200 \mathrm{yr}$ ago. Geology 25, 483-486.

Bahn, P.G., 1984. Pyrenean Prehistory. A Palaeoeconomic Survey of the French Sites Aris \& Phillips Ltd, Warminster. 511 pp.

Bal, M.-C., Rendu, C., Ruas, M.-P., Campmajo, P., 2010. Paleosol charcoal: reconstructing vegetation history in relation to agro-pastoral activities since the Neolithic. A case study in the Eastern French Pyrenees. Journal of Archaeological Science 37, 1785-1797.

Berthe, M., 1984. Famine et épidemie dans les campagnes navaraisses à la fin du Moyen Age. Paris, 2 vol.

Beug, H.-J., 2004. Leitfaden der Pollenbestimmung für Mitteleuropa und angrenzende Gebiet. Pfeil, München (D). 542 pp.

Blaauw, M., Van der Plicht, J., Van Geel, B., 2004. Radiocarbon dating of bulk peat samples from raised bogs: non-existence of a previously reported "reservoir effect"? Quaternary Science Reviews 23, 1537-1542.

Bonnassie, P., 1989. La croissance agricole du Haut Moyen Age dans la Gaule du Midi et le Nord est de la peninsule ibérique. La croissance agricole du Haut Moyen Age: Flaran, 10, pp. 13-35.

Carcaillet, C., 1998. A spatially precise study of Holocene fire history, climate and human impact within the Maurienne valley, North French Alps. Journal of Ecology 86, 384-396.

Carcaillet, C., Bouvier, M., Frechette, B., Larouche, A.C., Richard, P.J.H., 2001. Comparison of pollen slide and sieving methods in lacustrine charcoal analyses for local and regional fire history. The Holocene 11, 467-476.

Carozza, L., Galop, D., 2008. Le dynamisme des marges, Peuplement et exploitation des espaces de montagne durant l'âge du Bronze. In: Guilaine, J. (Ed.), Villes, villages, campagnes de l'Age du Bronze. Editions Errance.

Carrión, J.S., Sánchez-Gómez, P., Mota, J.F., Riker, Y., Chain, C., 2003. Holocene vegetation dynamics, fire and grazing in the Sierra de Gador, southern Spain. The Holocene 13, 839-849.

Clark, J.S., 1995. Particle-size evidence for source areas of charcoal accumulation in late Holocene sediments of eastern North American lakes. Quaternary Research 43, 80-89.

Clark, J.S., Patterson, W.A., 1997. Background and local charcoal in sediments: scales of fire evidence in the palaeorecord. In: Clark, J.S., Cachier, H., Goldammer, J.G., Stocks, B. (Eds.), Sediments Records of Biomass Burning and Global Change. : NATO ASI Series. Springer, Berlin, pp. 23-49.

Clark, J.S., Merkt, I., Muller, H., 1989. Post-glacial fire, vegetation and human history of the northern Alpine Forelands, southwestern Germany. Journal of Ecology 77, $897-925$.

Dupias, G., 1985. Végétation des Pyrénées. Notice détaillée de la partie pyrénéenne des feuilles (69, 70, 71, 72, 76, 77, 78). Ed. CNRS, Paris. 209 pp.

Enache, M.D., Cumming, B.F., 2006. Tracking recorded fires using charcoal morphology from the sedimentary basin of Prosser Lake, British Columbia (Canada). Quaternary Research 65, 282-292.

Enache, M.D., Cumming, B.F., 2007. Charcoal morphotypes in lake sediments from British Columbia (Canada): an assessment of their utility for the reconstruction of past fire and precipitation. Journal of Paleolimnology 38, 347-363.

Enache, M.D., Cumming, B.F., 2009. Extreme fires under warmer and drier conditions inferred from sedimentary charcoal morphotypes from Opatcho Lake, central British Columbia, Canada. The Holocene 19, 835-846.

Faegri, K., Iversen, J., 1989. Textbook of Pollen Analysis, 4th edition. Chichester, 328 pp.

Galop, D., 1998. La forêt, l'homme et le troupeau dans les Pyrénées. 6000 ans d'histoire de l'environnement entre Garonne et Méditerranée. GEODE, Laboratoire d'écologie terrestre, FRAMESPA, Toulouse.

Galop, D., 2000. La croissance médiévale sur le versant nord des Pyrénées à partir des données palynologiques. In: Berthe, M., Cursente, B. (Eds.), Villages Pyrénéens Morphogenèse d'un habitat de montagne. CNRS, UTM, pp. 45-54.

Galop, D., 2001. Les apports de la palynologie à l'histoire rurale : l'exemple de la longue durée des activités agro-pastorales pyrénéennes. Etudes Rurales 153-154 $127-138$.

Galop, D., 2005. Les transformations de l'environnement pyrénéen durant l'Antiquité : l'état de la question à la lumière des données polliniques. Aquitania Supplément 13, 317-327.

Galop, D., 2006. La conquête de la montagne Pyrénéenne au Néolithique. Chronologie, rythmes et transformations des paysages à partir des données polliniques. In: Guilaine, J. (Ed.), Populations néolithiques et environnement. Editions Errance pp. 279-295.

Galop, D., Jalut, G., 1994. Differential human impact and vegetation history in two adjacent Pyrenean valleys in the Ariège basin, southern France, from 3000 B.P. to the present. Vegetation History and Archaeobotany 3, 225-244.

Galop, D., Vanniere, B., Fontugne, M., 2002. Human activities and fire history since 4500 BC on the northern slope of the Pyrenees: a record from Cuguron (Central Pyrenees, France). In: Thièbault, S. (Ed.), Charcoal analysis: methodological approaches, palaeological results and wood uses. Proceedings of the Second International Meeting of Anthracology, Paris, September 2000: BAR International Series, 1063, pp. 43-51.

Galop, D., Carozza, L., Marembert, F., Bal, M.-C., 2007. Activités pastorales et climat durant l'âge du Bronze dans les Pyrénées : l'état de la question à la lumière des données environnementales et archéologiques. In: Richard, H., Magny, M., Mordant, C. (Eds.), 
Environnements et cultures à l'âge du Bronze en Europe occidentale. Editions du CTHS, pp. 107-119.

Galop, D., Houet, T., Mazier, F., Leroux, G., Rius, D., 2011. Grazing activities and biodiversity in the Pyrenees: new insight on high altitude ecosystems in the framework of a Human-Environment Observatory. PAGES News 19, 53-55.

Gavin, D.G., Brubaker, L.B., Lertzman, K.P., 2003. An 1800-year record of the spatial and temporal distribution of fire from the west coast of Vancouver Island, Canada. Canadian Journal of Forest Research 33, 576-586.

Gavin, D.G., Hu, F.S., Lertzman, K.P., Corbett, P., 2006. Weak climatic control of standscale fire history during the late Holocene. Ecology 87, 1722-1732.

Gil-Romera, G., Carrión, J.S., Pausas, J.G., Sevilla-Callejo, M., Lamb, H.F., Fernandez, S, Burjachs, F., 2010. Holocene fire activity and vegetation response in SouthEastern Iberia. Quaternary Science Reviews 29, 1082-1092.

Grimm, E., 1987. CONISS: a Fortran 77 program for stratigraphically constrained cluster analysis by the method of incremental sum of squares. Computer and Geosciences $13,13-35$.

Guilaine, J., 1994. La mer partagée. La Méditerranée avant l'écriture, 7000-2000 avant Jésus-Christ. Hachette. 453 pp.

Heegaard, E., Birks, H.J.B., Telford, R.J., 2005. Relationships between calibrated ages and depth in stratigraphical sequences: an estimation procedure by mixed-effect regression. The Holocene 15, 612-618.

Heyerdahl, E.K., Brubaker, L.B., Agee, J.K., 2001. Spatial controls of historical fire regimes: a multiscale example from the interior west, USA. Ecology 82, 660-678.

Higuera, P.E., Gavin, D.G., Bartlein, P.J., Hallett, D.J., 2010. Peak detection in sedimentcharcoal records: impacts of alternative analytical methods on fire-history interpretation. International Journal of Wildland Fire 19, 996-1014.

Iversen, J., 1956. Forest clearance in the Stone Age. Scientific American 194, 36-41.

Jalut, G., Aubert, S., Galop, D., Fontugne, M., Belet, J.M., 1996. Type regions F-zg and F-r, the northern slope of the Pyrenees. In: Berglund, B.E., Birks, H.J.B., Ralska-Jaziewczowa M., Wright, H.E. (Eds.), Palaeoecological Events During the Last 15000 years-Regiona Syntheses of Palaeoecological Studies of Lakes and Mires in Europe. J. Wiley \& Sons, pp. 612-632.

Joerin, U.E., Stocker, T.F., Schluchter, C., 2006. Multicentury glacier fluctuations in the Swiss Alps during the Holocene. The Holocene 16, 697-704.

Joerin, U.E., Nicolussi, K., Fischer, A., Stocker, T.F., Schlüchter, C., 2008. Holocene optimum events inferred from subglacial sediments at Tschierva Glacier, Eastern Swiss Alps. Quaternary Science Reviews 27, 337-350.

Kaltenrieder, P., Procacci, G., Vannière, B., Tinner, W., 2010. Postglacial vegetation and fire history of the Euganean Hills (Colli Euganei) as recorded by sedimentary pollen and charcoal series from Lago della Costa (northeastern Italy). The Holocene 20, 679-695.

Long, C.J., Whitlock, C., Bartlein, P.J., Millspaugh, S.H., 1998. A 9000-year fire history from the Oregon Coast Range, based on a high resolution charcoal study. Canadian Journal of Forest Research 28, 774-787.

Lynch, J.A., Clark, J.S., Stocks, B.J., 2004. Charcoal production, dispersal and deposition from the Fort Providence experimental fire: interpreting fire regimes from charcoal records in the boreal forests. Canadian Journal of Forest Research 34, 1642-1656.

Magny, M., 2004. Holocene climate variability as reflected by mid-European lake-level fluctuations and its probable impact on prehistoric human settlements. Quaternary International 113, 65-79.

Magny, M., Peyron, O., Gauthier, E., Rouèche, Y., Bordon, A., Billaud, Y., Chapron, E., Marguet, A., Pétrequin, P., Vannière, B., 2009. Quantitative reconstruction of climatic variation during the Bronze Age based on pollen and lake-level data in the NW Alps, France. Quaternary International 200, 102-110.

Mardones, M., Jalut, G., 1983. La tourbière de Biscaye (alt. 409m, Hautes-Pyrénées): Approche paléoécologique des 45000 dernières années. Pollen et Spores 25 163-212.

Marlon, J., Bartlein, P.J., Whitlock, 2006. Fire-fuel-climate linkages in the northwestern USA during the Holocene. The Holocene 16, 1059-1071.

Marlon, J.R., Bartlein, P.J., Carcaillet, C., Gavin, D.G., Harrison, S.P., Higuera, P.E., Joos, F., Power, M.J., Prentice, I.C., 2008. Climate and human influences on global biomass burning over the past two millennia. Nature Geoscience. doi:10.1038/ ngeo313.

Métailié, J.P., 1981. Le feu pastoral dans les Pyrénées centrales (Barousse, Oueil, Larboust). Ed. CNRS, Paris. 294 pp.

Miras, Y., Ejarque, A., Riera, S., Palet, J.M., Orengo, H., Euba, I., 2007. Dynamique holocène de la végétation et occupation des Pyrénées andorranes depuis le Néolithique ancien, d'après l'analyse pollinique de la tourbière de Bosc dels Estanyons (2180m Vall de Madriu, Andorre). Comptes Rendus Palevol 6, 291-300.

Monna, F., Galop, D., Carozza, L., Tual, M., Beyrie, A., Marembert, F., Chateau, C., Dominik, J. Grousset, F.E., 2004. Environmental impact of Basque mining and smelting recorded in a high ash minerogenic peat deposit. Science of the Total Environment 327 197-214.

Montané, F., Casals, P., Taull, M., Lambert, B., Dale, M.R.T., 2009. Spatial patterns of shrub cover after different fire disturbances in the Pyrenees. Annals of Forest Science 66 (612), 1-7.

Nicolussi, K., Kaufmann, M., Patzelt, G., van der Plicht, J., Thurner, A., 2005. Holocene tree-line variability in the Kauner Valley, indicated by dendrochronological analy sis of living trees and subfossils logs. Vegetation History and Archaeobotany 14 221-234.

Nicolussi, K., Kaufmann, M., Melvin, T.M., van der Plicht, J., Schießling, P., Thurner, A. 2009. A 9111 year long conifer tree-ring chronology for the European Alps: base for environmental and climatic investigations. The Holocene 19, 909-920.

Noti, R., van Leeuwen, J.F.N., Colombaroli, D., Vescovi, E., Pasta, S., La Mantia, T., Tinner, W., 2009. Mid- and late-Holocene vegetation and fire history at Biviere di Gela, a coastal lake in southern Sicily, Italy. Vegetation History and Archaeobotany 18 371-387.
Olsson, F., Gaillard, M.-J., Lemdahl, G., Greisman, A., Lanos, P., Marguerie, D., Marcoux, N., Skoglund, P., Wäglind, J., 2010. A continuous record of fire covering the last 10500 calendar years from southern Sweden-the role of climate and human activities, 2010. Palaeogeography, Palaeoclimatology, Palaeoecology 291, 128-141.

Pausas, J.G., 2004. Changes in fire and climate in the eastern Iberian Peninsula (Mediterranean basin). Climatic Change 63 (3), 337-350.

Peña-Chocarro, L., Zapata, L., Iriarte, M.J., González Morales, M., Straus, L.G., 2005. The oldest agriculture in northern Atlantic Spain: new evidence from El Mirón Cave (Ramales de la Victoria, Cantabria). Journal of Archaeological Science 32, 579-587.

Pitkanen, A., 2000. Fire frequency and forest structure at a dry site between AD440 and 1110 based on charcoal and pollen records from a laminated lake sediment in Eastern Finland. The Holocene 10 (2), 221-228.

Power, M.J., Marlon, J., Ortiz, N., Bartlein, P.J., Harrison, S.P., Mayle, F.E., Ballouche, A., Bradshaw, R.H.W., Carcaillet, C., Cordova, C., Mooney, S., Moreno, P.I., Prentice, I.C., Thonicke, K., Tinner, W., Whitlock, C., Zhang, Y., Zhao, Y., Ali, A.A., Anderson, R.S., Beer, R., Behling, H., Briles, C., Brown, K.J., Brunelle, A., Bush, M., Camill, P., Chu, G.Q., Clark, J., Colombaroli, D., Connor, S., Daniau, A.-L., Daniels, M., Dodson, J., Doughty, E., Edwards, M.E., Finsinger, W., Foster, D., Frechette, J., Gaillard, M.-J., Gavin, D.G., Gobet, E., Haberle, S., Hallett, D.J., Higuera, P., Hope, G., Horn, S., Inoue, J., Kaltenrieder, P., Kennedy, L., Kong, Z.C., Larsen, C., Long, C.J., Lynch, J., Lynch, E.A., McGlone, M., Meeks, S., Mensing, S., Meyer, G., Minckley, T., Mohr, J., Nelson, D.M., New, J., Newnham, R., Noti, R., Oswald, W., Pierce, J., Richard, P.J.H., Rowe, C., Sanchez-Goni, M.F., Shuman, B.N., Takahara, H., Toney, J., Turney, C., UrregoSanchez, D.H., Umbanhowar, C., Vandergoes, M., Vannière, B., Vescovi, E., Walsh, M., Wang, X., Williams, N., Wilmshurst, J., Zhang, J.H., 2008. Changes in fire regimes since the Last Glacial Maximum: an assessment based on a global synthesis and analysis of charcoal data. Climate Dynamics 30, 887-907.

Préfecture des Hautes-Pyrénées, 2007. Plan départemental de Protection des Forêts Contre les Incendies. 58 pp. www.risquesmajeurs-hautes-pyrenees.pref.gouv.fr. (last downloaded : 22/02/2011)

R Development Core Team, 2009. R: A language and environment for statistical computing. R Foundation for Statistical Computing, Vienna, Austria http://www.R-projetc.org.

Reille, M., 1992-98. Pollen et spores d'Europe et d'Afrique du Nord. Laboratoire de Botanique Historique et Palynologie, Marseille. 3 vols

Reille, M., Andrieu, V., 1995. Late-Pleistocene and Holocene in the Lourdes Basin (western Pyrenees, France): new pollenanalytical and chronological data. Vegetation History and Archaeobotany 4, 1-21.

Reimer, P.J., Baillie, M.G.L., Bard, E., Bayliss, A., Beck, J.W., Blackwell, P.G., Bronk Ramsey, C., Buck, C.E., Burr, G.S., Edwards, R.L., Friedrich, M., Grootes, P.M., Guilderson, T.P., Hajdas, L. Heaton, T.J., Hogg, A.G., Hughen, K.A., Kaiser, K.F., Kromer, B., McCormac, F.G., Manning S.W., Reimer, R.W., Richards, D.A., Southon, J.R., Talamo, S., Turney, C.S.M., van der Plicht, J., Weyhenmeyer, C.E., 2009. IntCal09 and Marine09 radiocarbon age calibration curves, 0e50,000 years cal BP. Radiocarbon 51 (4), 1111e1150.

Renssen, H., Seppä, H., Heiri, O., Roche, D.M., Goosse, H., Fichefet, T., 2009. The spatial and temporal complexity of the Holocene thermal maximum. Nature Geoscience 2, 411-414.

Rhodes, A.N., 1998. A method for the preparation and quantification of microscopic charcoal from terrestrial and lacustrine sediment cores. The Holocene 8, 113-117.

Ribet N., 2009. Parcours du feu. Techniques de brûlage à feu courant et socialisation de la nature dans les Monts d'Auvergne et les Pyrénées centrales. Thèse de Doctorat, EHESS Paris.

Rius, D., Vanniere, B., Galop, D., 2009. Fire frequency and landscape management in the north-western Pyrenean piedmont (France) since the early Neolithic $(8000 \mathrm{cal}$. BP). The Holocene 19, 847-859.

Rius, D., Vannière, B., Galop, D., Richard, H., 2011. Holocene fire regime changes from multiple-site sedimentary charcoal analyses in the Lourdes basin (Pyrenees, France). Quaternary Science Reviews 30, 1696-1709.

Stähli, M., Finsinger, W., Tinner, W., Allgöwer, B., 2006. Wildfire history and fire ecology of the Swiss National Park (Central Alps): new evidence from charcoal, pollen and plant macrofossils. The Holocene 16, 805-817.

Stuiver, M., Reimer, P.J., 1993. Extended 14C data base and revised CALIB $3.014 \mathrm{C}$ age calibration program. Radiocarbon 35, 215-230.

Tinner, W., Hubschmid, P., Wehrli, M., Ammann, B., Conedera, M., 1999. Long-term forest fire ecology and dynamics in southern Switzerland. Journal of Ecology 87, 273-289.

Tinner, W., Conedera, M., Gobet, E, Hubschmid, P., Wehrli, M. Ammann, B., 2000. A palaeoecological attempt to classify fire sensitivity of trees in the southern Alps. The Holocene 10, 565-574

Tinner, W., Conedera, M., Ammann, B., Lotter, A.F., 2005. Fire ecology north and south of the Alps since the last ice age. The Holocene 15, 1214-1226.

Tinner, W., Hu, F.S., Beer, R., Kaltenrieder, P., Scheurer, B., Krähenbühl, U., 2006. Postglacial vegetational and fire history: pollen, plant macrofossil and charcoal records from two Alaskan lakes. Vegetation History and Archaebotany 15, 279-293.

Tinner, W., van Leeuwen, J.F.N., Colombaroli, D., Vescovi, van der Knaap, W.O., Henne, P.D., Pasta, S., D'angelo, S., La Mantia, T., 2009. Holocene environmental changes at Gorgo Basso, a coastal lake in southern Sicily, Italy. Quaternary Science Reviews 28, 1498-1510.

Turner, R., Roberts, N., Jones, M.D., 2008. Climatic pacing of Mediterranean fire histories from lake sedimentary charcoal. Global and Planetary Change 63, 317-324.

Umbanhowar, C.E., McGrath, M.J., 1998. Experimental production and analysis of microscopic charcoal from wood, leaves and grasses. The Holocene 8, 341-346.

Valdeyron, N., 2008. The mesolithic in France. In: Bailey, G., Spikins, P. (Eds.), Mesolithic Europe. Cambridge University Press, pp. 182-202.

Valsecchi, V., Carraro, G., Conedera, M., Tinner, W., 2010. Late-Holocene vegetation and land-use dynamics in the southern Alps (Switzerland) as a basis for nature protection and forest management. The Holocene 20, 483-495.

Vanniere, B., Galop, D., Rendu, C., Davasse, B., 2001. Feu et pratiques agro-pastorales dans les Pyrénées-Orientales : le cas de la montagne d'Enveitg (Cerdagne, Pyrénées-Orientales, France). Revue Géographique des Pyrénées et du Sud-Ouest 11, 29-42. 
Vannière, B., Colombaroli, D., Chapron, E., Leroux, A., Tinner, W., Magny, M., 2008. Climate versus human-driven fire regimes in Mediterranean landscapes: the Holocene record of Lago dell'Accesa (Tuscany, Italy). Quaternary Science Reviews 27, 1181-1196.

Vannière, B., Colombaroli, D., Roberts, N., 2010. A fire paradox around the Mediterranean. PAGES News 18, 63-65.

Vannière, B., Power, M.J., Roberts, N., Tinner, W., Carrión, J., Magny, M., Bartlein, P., Colombaroli, D., Daniau, A.-L., Finsinger, W., Gil-Romera, G., Kaltenrieder, P. Magri, D., Pini, R., Sadori, L., Turner, R., Valsecchi, V., Vescovi, E., 2011. Circum-
Mediterranean fire activity and climate changes during the mid-Holocene environmental transition (8500-2500 cal. BP). The Holocene 21, 53-73.

Whitlock, C., Millspaugh, S.H., 1996. Testing the assumptions of fire-history studies: an examination of modern charcoal accumulation in Yellowstone National Park, USA The Holocene 6, 7-15.

Whitlock, C., Higuera, P.E., McWethy, D.B., Briles, C.E., 2010. Paleoecological perspectives on fire ecology: revisiting the fire-regime concept. The Open Ecology Journal 3, 6-23.

Zapata, L., Peña-Chocarro, L., Pérez-Jordá, G., Stika, H.-S., 2004. Early Neolithic agriculture in the Iberian Peninsula. Journal of World Prehistory 18, 283-325. 